\title{
Pemanfaatan TIK Sebagai Media Pembelajaran dan Sumber Belajar oleh Guru TIK
}

\author{
Isnania Lestari ${ }^{1}$, Meko Hendwi Pratama ${ }^{2}$ \\ ${ }^{1,2}$ Program Studi Pendidikan Teknologi Informasi dan Komputer, IKIP PGRI Pontianak \\ e-mail : isnanialestari@gmail.com ${ }^{1}$, mekohendy@gmail.com ${ }^{2}$
}

(Received: 15 Oktober 2020 / Accepted: 18 November 2020 / Published Online: 20 Desember 2020)

\begin{abstract}
Abstrak
Teknologi Informasi dan Komputer (TIK) saat ini telah dimanfaatkan disegala bidang, termasuk pendidikan. Salah satu pemanfaatan TIK di bidang Pendidikan adalah untuk Media pembelajaran dan juga sumber belajar yang dapat digunakan oleh guru. Penelitian ini bertujuan untuk mengetahui sejauh mana kompetensi ataupun kemampuan guru khususnya mata pelajaran TIK dalam memanfaatkan TIK baik sebagai media pembelajaran maupun sumber belajar. Pemanfaatan TIK dilakukan untuk mempermudah guru dalam melaksanakan proses pembelajaran. Metode penelitian yang digunakan adalah deskriptif dengan bentuk survey. Alat pengumpul data yang digunakan adalah angket dan juga wawancara. Teknik analisis data yang digunakan adalah deskriptif kuantitatif untuk mengolah data angket dan deskriptif kualitatif untuk mengolah data wawancara. Berdasarkan data yang diperoleh, pemanfaatan TIK sebagai Media Pembelajaran dan Sumber Belajar oleh guru SMA Sederajat di Kecamatan Bunguran Timur Kabupaten Natuna berada pada persentase diatas $80 \%$ dengan kategori tinggi. Hal ini menunjukan bahwa kemampuan guru dalam memanfaatkan TIK sudah sangat baik. Media pembelajaran yang paling sering digunakan adalah aplikasi pengolah persentasi dan proyektor. Sedangkan sumber belajar yang paling banyak digunakan adalah internet.
\end{abstract}

Kata Kunci: Media Pembelajaran, Sumber Belajar, TIK

\begin{abstract}
Information and computer technology (ICT) is currently being used in all fields, including education. One of the uses of ICT in the field of education is for learning media and learning resources that can be used by teachers. This study aims to determine the extent to which the competence or ability of teachers, especially in ICT subjects, in utilizing ICT both as a medium of learning and a learning resource. The use of ICT is carried out to make it easier for teachers to implement the learning process. The research method used is descriptive with a survey form. The data collection tools used were questionnaires and interviews. The data analysis technique used is quantitative-descriptive to process questionnaire data and qualitative-descriptive to process interview data. Based on the data obtained, the use of ICT as a Learning Media and Learning Resources by Equivalent High School teachers in East Bunguran District, Natuna Regency is at a percentage above $80 \%$ with a high category. This shows that the teacher's ability to use ICT is very good. The learning media is majority often used are presentation processing applications and projectors. Meanwhile, the most widely used learning resource is the Internet.
\end{abstract}

Keywords: ICT, Learning Media, Learning Resources

\section{PENDAHULUAN}

Pendidikan merupakan salah satu faktor utama untuk mewujudkan masyarakat yang berkualitas. Sudarwan (2012) menjelaskan bahwa Pendidikan adalah proses permatabatan manusia menuju puncak optimasi potensi kognitif, afektif, dan psikomotorik yang dimilikinya. Proses Pendidikan tersebut dapat mencapai tujuan yang diinginkan dengan melakukan proses pembelajaran yang tepat. Seperti yang dikatakan oleh Miarso dalam (Lestari, 2015) bahwa faktor yang mendukung terwujudnya proses pembelajaran yang 
berkualitas salah satunya adalah penggunaan dan pemanfaatan teknologi informasi dan komunikasi (TIK) dalam proses pendidikan dan pembelajaran. Hasil penelitian yang dilakukan oleh Cholik (2017), telah membuktikan bahwa ternyata perkembangan teknologi, informasi dan komunikasi dapat diintegrasikan dalam proses pembelajaran.

Dengan perkembangan teknologi saat ini, guru di tuntut untuk memiliki kompetensi yang baik dalam menggunakan TIK. Seperti yang tertera dalam Kemendiknas (2007) bahwa salah satu kompetensi pedagogik yang harus dimiliki guru adalah memanfaatkan teknologi informasi dan komunikasi untuk kepentingan penyelenggaraan kegiatan pengembangan yang mendidik. Karena pada kenyataan di lapangan, banyak guru yang belum memiliki kompetensi yang baik dalam menggunakan TIK. Dalam penelitian yang dilakukan Lestari (2015) dijelaskan bahwa kendala pemanfaatan TIK oleh guru antara lain guru tidak memiliki kemampuan TIK dan juga tidak ada kemauan guru untuk memanfaatkannya. Sedangkan banyak jenis TIK yang dapat dimanfaatkan dalam proses pembelajaran.

Terdapat empat SMA sederajat di Bunguran timur. Masalah utama di sekolah tersebut adalah masih kurangnya guru TIK yang berasal dari lulusan Pendidikan TIK. Oleh karena itu, pemanfaatan TIK dalam pembelajaran belum maksimal. Hal ini dijelaskan dari hasil wawancara kepada salah satu guru TIK di SMA tersebut, karena guru TIK bukan lulusan Pendidikan TIK maka guru tidak memiliki kemampuan TIK yang mumpuni. Hal tersebut berpengaruh terhadap pemanfaatan TIK dalam pembelajaran. Dikarenakan perkembangan teknologi yang semakin pesat dan juga tuntutan peningkatan kompetensi pemanfaatan TIK oleh guru khususnya untuk guru mata pelajaran TIK.

Dalam pembelajaran, guru dapat memanfaatkan TIK dalam segala hal. Diantaranya adalah sebagai media pembelajaran dan sumber belajar. Sebagai media, TIK dimanfaatkan sebagai alat untuk mempermudah guru dalam menyampaikan pembelajaran. Musfiqon (2012) menjelaskan bahwa media pembelajaran adalah alat bantu yang berfungsi untuk menjelaskan sebagian dari keseluruhan program pembelajaran yang sulit dijelaskan secara verbal. Jadi dapat disimpulkan bahwa pemanfaatan TIK sebagai media pembelajaran adalah sebagai alat bantu untuk penyampaian materi pada proses pembelajaran supaya lebih mudah diterima oleh siswa. Selain itu, (Tafonao, 2018) menerangkan bahwa media pembelajaran dapat berperan dalam mengatasi kebosanan dalam belajar, selain itu media bisa menjadi salah satu metode dalam mengatasi segala macam persoalan dalam mengajar, dan juga membantu pemberi pembelajaran memberi berbagai informasi yang koprehensip kepada peserta didik. Berdasarkan hasil penelitian yang telah dilakukan oleh (Chaidar 2014; Dewi \& Hilman 2019), media pembelajaran berbasis TIK yang paling sering digunakan dalam pembelajaran adalah berupa Komputer yakni aplikasi pengolah slide persentasi dan juga LCD proyektor. Dengan hanya memanfaatkan kedua media tersebut, siswa biasanya akan lebih faham dan tertarik dengan pembelajaran.

Sumber belajar adalah segala macam sumber yang ada di luar diri siswa yang keberadaanya memudahkan terjadinya proses belajar (Musfiqon, 2012). Sumber belajar yang paling umum digunakan oleh guru adalah buku dan modul pembelajaran. Namun dengan memanfaatkan TIK guru dapat memperoleh informasi yang tak terbatas yang dapat digunakan sebagai sumber belajar utama maupun referensi tambahan. Salah satu pemanfaatan TIK untuk sumber belajar adalah pemanfaatan jaringan internet. Adri dalam Setiyani (2010) mengatakan, pemanfaatan jaringan internet sebagai sumber dan sarana pembelajaran dapat diimplementasikan untuk melakukan Browsing, Resourcing, dan Searching. Berdasarkan penelitian yang telah dilakukan oleh Husaini (2014), melalui internet layanan informasi dapat diberikan sebagai sumber belajar yang dapat dipelajari sesuai dengan kecepatan belajar peserta didik. Melalui internet, guru dapat memperoleh banyak informasi yang dapat dijadikan referensi tambahan untuk digunakan sebagai materi pembelajaran di kelas. Namun 
terdapat kendala utama dalam memanfaatakan jaringan dan internet sebagai sumber belajar. Yakni koneksi dan signal yang tidak merata di setiap daerah di Indonesia.

Penelitian ini bertujuan untuk mengetahui sejauh mana kompetensi ataupun kemampuan guru khususnya mata pelajaran TIK dalam memanfaatkan TIK baik sebagai media pembelajaran maupun sumber belajar. Anshori (2018) mengatakan bahwa upaya pemecahan permasalahan pendidikan terutama masalah yang berhubungan dengan kualitas pembelajaran, dapat ditempuh dengan cara penggunaan berbagai sumber belajar dan penggunaan media pembelajaran. Karena kemampuan guru dalam mengintegerasikan TIK ke dalam pembelajaran juga akan mempengaruhi kemampuan siswa secara signifikan dalam mencapai tujuan pendidikan.

\section{METODE}

Metode penelitian yang digunakan adalah metode deskriptif. Metode ini digunakan untuk mengetahui sejauh mana guru TIK dalam memanfaatkan TIK dalam media pembelajaran dan sumber belajar di SMA Se derajat di Kecamatan Bunguran Timur Kabupaten Natuna. Bentuk penelitian yang sesuai dengan metode yang digunakan dalam penelitian ini adalah survei (survey studies). Dengan jumlah populasi adalah 4 orang guru TIK yang berasal dari 4 SMA yang ada Kecamatan Bunguran Timur Kabupaten Natuna. Teknik sampling yang digunakan adalah sampel jenuh, karena jumlah populasi yang sedikit, maka seluruh populasi tersebut dijadikan sampel.

Dalam penelitian ini, menggunakan tiga teknik pengumpulan data yaitu teknik komunikasi tidak langsung, dengan alat yang digunakan adalah berupa angket tertutup dengan 5 buah pilihan jawaban. Angket tersebut digunakan untuk mengetahui sejauh mana kompetensi Guru SMA Sederajat dalam menggunakan TIK sebagai media pembelejaran dan sumber belajar. Selanjutnya teknik komunikasi langsung dengan alat yang gunakan adalah wawancara tidak terstruktur. Wawancara digunakan untuk mengetahui sejauh mana Guru SMA Sederajat menggunakan TIK sebagai Media Pembelajaran dan Sumber Belajar. Dan yang terakhir adalah analisis dokumen. Hal ini dilakukan untuk mengumpulkan data - data pendukung baik berupa dokumen, foto maupun video yang menggambarkan pemanfaatan TIK di SMA Sederajat di Kecamatan Bunguran Timur Kabupaten Natuna.

Terdapat dua jenis data yang diperolah dari pengumpulan data tersebut, yakni data kualitatif dan kuantitatif. Data kualitatif dibuat uraian dalam bentuk bahasa prosa, kemudian dikaitkan dengan data lainnya, sedangkan Teknik analisis data kuantitatif yang digunakan dalam penelitian ini adalah deskriptif kuantitatif dengan presentase. Selanjutnya adalah mendeskripsikan persentase data tersebut berdasarkan kategori skor penelitian.

\section{HASIL DAN PEMBAHASAN Hasil}

Pemanfaatan TIK sebagai media pembelajaran yang paling umum digunakan adalah Aplikasi pengolah slide persentasi dan LCD Proyektor. Sedangkan sebagai sumber belajar, yang sering digunakan adalah internet. Berdasarkan hasil pengumpulan data, diketahui sejauh mana pemanfaatan TIK yang dilakukan oleh guru TIK SMA sederajat di kecamatan Bunguran Timur. Hasil pengolahan data dapat disajikan dalam bentuk skor, persentase dan juga deskripsi hasil analisis data. Hasil pengolahan data tersebut dapat dilihat dalam tabel 1 sebagai berikut:

Tabel 1. Hasil Analisis Data

\begin{tabular}{cccc}
\hline No & \multicolumn{1}{c}{ Variabel } & Skor & Persentase \\
\hline 1 & TIK Sebagai Media Pembelajaran & 505 & $84 \%$ \\
2 & TIK Sebagai Sumber Belajar & 497 & $82 \%$ \\
\hline
\end{tabular}


Berdasarkan tabel tersebut, dapat dilihat bahwa perolehan skor untuk seluruh variabel adalah di atas $80 \%$. Hal ini menunjukan bahwa pemanfaatan TIK baik sebagai media pembelajaran maupun sumber belajar berada di kategori tinggi. Berdasarkan data survey maupun wawancara, guru menerangkan bahwa TIK sangat membantu dalam proses pembelajaran di kelas. Sebagai media pembelajaran, menunjukan bahwa sebagian besar guru TIK SMA sederajat di kecamatan Bunguran Timur menggunakan aplikasi pengolah persentasi dan proyektor sebagai media pembelajaran utama. Namun terdapat beberapa guru yang memanfaatkan aplikasi pembuat animasi dan juga aplikasi editing audio video untuk membuat media pembelajarannya lebih menarik. Selain itu, media pembelajaran berbasis web juga telah digunakan oleh guru untuk menunjang pembelajarannya di kelas. Hal ini menunjukan bahwa guru TIK telah berusaha memaksimalkan kompetensi yang dimilikinya untuk membuat media pembelajaran yang baik dan menarik bagi siswa

Sebagai sumber belajar, guru SMA memanfaatkan TIK untuk mencari sumber belajar melalui internet. Internet merupakan wadah pencarian informasi yang sangat luas dan tak terbatas, maka dari itu guru banyak memanfaatkannya. Kriteria guru - guru tersebut tidak sama dalam memanfaatkan TIK khususnya internet dalam mencari sumber belajar. Terdapat guru yang masih bergantung dengan buku sebagai sumber literasi utama dan internet digunakan sebagai sumber literasi tambahan. Tetapi, tidak sedikit pula guru yang menggunakan sumber informasi dari internet sebagai literasi utama. Namun apapun yang dilakukan oleh guru - guru tersebut adalah untuk memaksimalkan sumber belajar yang ada supaya dapat membantu guru dalam memaksimalkan proses pembelajaran. Persentasi pemanfaatan TIK sebagai sumber belajar adalah $82 \%$ dan termasuk kedalam kategori tinggi. Hal ini menjelaskan bahwa guru SMA Sederajat di Kecamatan Bunguran Timur Kabupaten Natuna telah memanfaatkan TIK dengan sangat baik.

Terdapat beberapa indikator yang digunakan untuk mengetahui bagaimana guru SMA sederajat memanfaatkan TIK sebagai media pembelajaran. Di dalam kelas, tantangan guru TIK tidak hanya menggunakan TIK sebagai media pembelajaran saja, namun guru mengenalkan TIK kepada siswa karena TIK merupakan salah satu mata pelajaran yang diajarkan disekolah. Dalam indikator yang telah diukur oleh peneliti, guru diharapkan memiliki kemampuan pemanfaatan TIK yang baik, karena guru tidak hanya memanfaatkan TIK untuk diri sendiri, tetapi harus berbagi ilmu kepada siswa mengenai perkembangan dan pemanfaatan TIK itu sendiri. Dalam tabel 2 berikut, dijelaskan hasil dari pengumpulan data mengenai pemanfaatan media pembeajaran oleh Guru.

Tabel 2. Perolehan Skor Indikator Media Pembelajaran

\begin{tabular}{clcc}
\hline No & \multicolumn{1}{c}{ Indikator } & Presentase & Kategori \\
\hline 1 & $\begin{array}{l}\text { Menyadarkan peserta didik akan potensi } \\
\text { perkembangan teknologi informasi dan komunikasi }\end{array}$ & $88 \%$ & $\begin{array}{c}\text { Sangat } \\
\text { Tinggi }\end{array}$ \\
2 & $\begin{array}{l}\text { Memotivasi kemampuan peserta didik untuk bisa } \\
\text { beradaptasi dan mengantisipasi perkembangan } \\
\text { teknologi informasi dan komunikasi }\end{array}$ & $81 \%$ & Tinggi \\
3 & $\begin{array}{l}\text { Mengembangkan kompetensi peserta didik dalam } \\
\text { menggunakan teknologi informasi dan komunikasi }\end{array}$ & $85 \%$ & Sangat \\
4 & $\begin{array}{l}\text { Mengembangkan kemampuan belajar berbasis TIK } \\
\text { Mengembangkan kemampuan belajar mandiri, } \\
\text { berinisiatif, inovatif, kreatif, dan bertanggung } \\
\text { jawab dalam penggunaan teknologi informasi dan } \\
\text { komunikasi }\end{array}$ & Tinggi \\
\hline
\end{tabular}


Berdasarkan indikator yang diukur dalam penelitian ini, terlihat bahwa guru memiliki perolehan persentase di atas $80 \%$ dengan kategori tinggi - sangat tinggi. Indikator pertama menjelaskan bahwa guru telah memberikan informasi kepada siswa mengenai potensi perkembangan TIK. Hal ini dilakukan selain karena guru tersebut mengajar mata pelajaran TIK, namun supaya siswa juga dapat selalu memanfaatkan TIK khususnya untuk media pembelajaran. Indikator selanjutnya adalah guru memotivasi siswa untuk beradaptasi dan mengantisipasi perkembangan TIK, hal ini dilakukan agar siswa terus belajar hal - hal baru karena TIK cepat sekali berkembang. Dengan mengembangkan potensi siswa dan juga memotivasi siswa untuk terus belajar mengenai TIK, secara tidak langsung guru juga telah berperan dalam mengembangkan kompetensi yang dimiliki oleh siswa dalam memanfaatkan TIK. Siswa dapat memanfaatkan TIK dalam pembelajaran agar dapat belajar dengan mudah, mandiri, inovatif dan juga kreatif. Hal ini dikarenakan cakupan TIK yang sangat luas.

Berdasarkan hasil tersebut, hal ini membuktikan bahwa guru memiliki kompetensi yang baik dalam memanfaatkan TIK. Tidak hanya sebagai media pembelajaran yang digunakan oleh guru itu sendiri, namun guru dapat mengenalkan TIK kepada siswa dengan baik. Seperti yang dikatakan oleh Sadiman dalam Anshori (2017) bahwa pemanfaatan media pembelajaran yang tepat dapat menambah kegairahan dalam belajar dan juga memungkinkan siswa belajar secara mandiri. Berdasarkan indikator - indikator tersebut, maka dapat disimpulkan bahwa TIK tidak hanya bisa dimanfaatkan oleh guru, namun siswa juga dapat memanfaatkannya supaya mempermudah proses pembelajaran.

Tidak hanya dimanfaatkan sebagai media pembelajaran, TIK juga dapat dimanfaatkan sebagai sumber belajar. Terdapat beberapa indikator yang digunakan untuk mengetahui sejauh mana kompetensi guru memanfaatkan TIK sebagai sumber belajar. Indikator tersebut menjelaskan mengenai tahapan - tahapan pemanfaatan TIK sebagai sumber belajar. Dalam tabel 3 berikut, dijelaskan hasil dari pengumpulan data mengenai pemanfaatan TIK sebagai sumber belajar.

Tabel 3. Perolehan Skor Indikator Sumber Belajar

\begin{tabular}{cccc}
\hline No & Indikator & Presentase & Kategori \\
\hline 1 & Mengidentifikasikan & $81 \%$ & Tinggi \\
2 & Mengembangkan & $80 \%$ & Tinggi \\
3 & Mengorganisasi & $83 \%$ & Tinggi \\
4 & Menggunakan & $85 \%$ & Sangat Tinggi \\
\hline
\end{tabular}

Pemanfaatan TIK sebagai sumber belajar juga berada di kategori tinggi hingga sangat tinggi. Terdapat 4 indikator yang diukur dalam pemanfaatan TIk sebagai sumber belajar. Dalam indikator mengidentifikasi, menunjukan angka $81 \%$ dengan kategori tinggi yang berarti bahwa guru dapat mengidentifikasi dengan baik fungsi dari TIK dan juga memilih jenis TIK yang dapat digunakan sebagai sumber belajar. Selanjutnya kategori mengembangkan ditunjukan dengan angka 80\%, Hal ini berarti guru dapat mengembangkan potensi dalam menggunakan jenis TIK yang dimanfaatkan sebagai sumber belajar. Indikator yang ketiga adalah mengorganisasi, hal ini menunjukan bahwa guru sudah dapat mengorganisasi segala hal yang didapat dari hasil memanfaatkan TIK tersebut. Angka yang ditunjukan dalam kategori ini adalah 83\% dengan kategori tinggi. Danyang terakhir adalah indikator menggunakan yang menunjukan angka $85 \%$ dengan kategori sangat tinggi. Angka ini menunjukan bahwa guru telah menggunakan TIK dengan baik sebagai sumber belajar. Berdasarkan data tersebut, terlihat bahwa guru tidak dapat melepaskan pemanfaatan TIK baik sebagai media pembelajaran maupun sumber belajar. 
Berdasarkan data yang telah didapat tersebut menunjukkan bahwa seluruh guru SMA Sederajat Di Kecamatan Bunguran Timur Kabupaten Nantuna memiliki konsep yang hampir sama dalam menggunakan TIK sebagai Media pembelajaran maupun Sumber Belajar.

\section{Pembahasan}

Media pembelajaran berbasis TIK memiliki cakupan yang sangat luas. Media pembelajaran yang dapat dibuat dengan menggunakan TIK tidak hanya berupa slide persentasi, tetapi dapat pula berupa video, audio dan juga aplikasi pembelajaran berbasis web ataupun android. Tujuan pemanfaatan TIK sebagai media pembelajaran adalah untuk mempermudah guru dalam menyampaikan pembelajaran. Selain itu, dapat menarik perhatian siswa dan juga memotivasi siswa dalam belajar. Rusman (2011) mengatakan bahwa media pembelajaran mengakomodir semua indera yang dimiliki oleh siswa, baik itu audio, visual maupun keduanya. Maka dari itu, guru harus bisa memaksimalkan potensi yang dimilikinya untuk membuat sebuah media pembelajaran yang menarik dan juga inovatif.

Hasil penelitian menunjukan bahwa persentase perolehan data angket untuk mengetahui pemanfaatan TIK sebagai media pembelajaran adalah $84 \%$. Sedangkan untuk perolehan skor tiap indikatornya adalah diatas $80 \%$. Angka tersebut menerangkan bahwa pemanfaatan TIK sebagai media pembelajaran berada di kategori tinggi. Hal ini dikarenakan guru TIK di SMA sederajat di Kecamatan Bunguran Timur Kabupaten Nantuna memiliki pengetahuan dan kompetensi yang baik dalam memanfaatkan TIK. Selain itu, guru TIK juga dituntut untuk mengikuti perkembangan teknologi yang ada, supaya dapat terus berinovasi dalam melakukan pembelajaran di kelas. Tugas guru mata pelajaran TIK berbeda dari guru mata pelajaran yang lain. Guru TIK, tidak hanya menggunakan teknologi untuk dirinya sendiri, melainkan harus bisa mengenalkan dan mengajak siswa menggunakan teknologi tersebut.

Sejalan dengan penelitian yang telah dilakukan oleh Chaidar (2014) yang menunjukan bahwa sebagian besar guru menggunakan komputer (aplikasi pengolah persentasi) sebagai media pembelajaran utama dikelas, dalam hasil penelitian ini pun menunjukan hasil yang sama. Hal ini karena media pembelajaran yang paling mudah dibuat dan umum digunakan adalah berupa slide persentasi. Walaupun sebagian guru hanya menggunakan slide persentasi, bukan berarti guru tidak memiliki kemampuan yang baik dalam menggunakan teknologi. Jika guru memaksimalkan semua fitur yang ada dalam aplikasi yang digunakan, guru dapat membuat sebuah media pembelajaran yang bagus dan menarik. Dewi \& Hilman (2019) juga menuliskan bahwa pemanfaatan komputer, proyektor dan juga slide persentasi merupakan salah satu media pembelajaran berbasis TIK yang dapat dimanfaatkan oleh guru. Namun terdapat satu orang guru TIK di SMA sederajat di kecamatan Bunguran Timur yang tidak hanya menggunakan slide persentasi dan proyektor, namun guru tersebut menggunakan aplikasi flash untuk membuat animasi yang dipergunakan untuk media pembelajaran dan juga memanfaatkan e-learning sebagai media pembelajaran tambahan.

Selain dimanfaatkan sebagai media pembelajaran, TIK juga dapat dimanfaatkan sebagai sumber belajar. Sumber belajar ini digunakan oleh guru sebagai bahan ajar yang akan disampaikan dalam proses pembelajaran. Sumber belajar utama yang dimiliki guru biasanya berupa buku paket yang tersedia di perpustakaan sekolah. Namun dengan memanfaatkan TIK, guru dapat memperoleh sumber belajar lain yang lebih luas. Salah satu pemanfaatan TIK sebagai sumber belajar adalah dengan menggunakans internet sebagai sarana untuk mendapatkan referensi atau informasi tambahan yang dapat digunakan dalam pembelajaran dikelas. Setiyani (2010) mengatakan beberapa manfaat internet bagi pengajar adalah dapat meningkatkan pengetahuan dan juga dapat berbagi sumber informasi. Internet menyediakan berbagai informasi yang di butuhkan oleh setiap penggunanya.

Berdasarkan hasil penelitian, seluruh guru TIK SMA sederajat di kecamatan Bunguran Timur telah memanfaatkan internet sebagai sumber belajar. Hal ini dilakukan karena 
mudahnya cara untuk mengakses internet, dan juga cakupan informasi yang ada dalam internet tersebut sangatlah luas. Dengan memanfaatkan internet, guru dapat mengakses buku, e-book, video pembelajaran dan jurnal yang dapat digunakan sebagai referensi tambahan bahkan referensi utama dalam pembelajaran. Hasil angket menunjukan perolehan persentase untuk indikator menggunakan TIK khususnya internet sebagai sumber belajar adalah 85\% dengan kategori sangat tinggi. Hal ini menunjukan bahwa guru telah fasih dalam menggunakan internet sebagai sumber belajar.

Seperti dijelaskan sebelumnya bahwa guru TIK tidak hanya memanfaatkan TIK untuk dirinya sendri, namun mengenalkan TIK juga kepada siswa. Maka yang menggunakan TIK sebagai media pembelajaran dan sumber belajar tidak hanya guru, tapi juga siswa. Effendi et al (2020) menjelaskan bahwa terjadi peningkatan hasil belajar dengan kategori besar terhadap siswa yang memanfaatkan TIK dalam pembelajaran. Selain itu, saat ini juga banyak siswa yang memanfaatkan internet. Melalui internet, siswa juga dapat berperan tidak hanya sebagai penikmat informasi tetapi dapat menganalisis berbagai data serta informasi yang telah diperoleh. Dalam penelitian yang dilakukan Nurdianti (2016) menjelaskan bahwa internet sebagai sumber belajar berpengaruh terhadap hasil belajar siswa. Jadi dapat disimpulkan bahwa pemanfaatan TIK khususnya internet sebagai sumber belajar tidak hanya membantu guru saja, namun siswa juga terbantu dalam melakukan pembelajaran.

\section{SIMPULAN}

Saat ini TIK tidak dapat terlepas dari semua aspek kehidupan. Salah satunya adalah dunia pendidikan. TIK dapat dimanfaatkan sebagai media pembelajaran dan juga sumber belajar. Berdasarkan hasil penelitian yang dilakukan, pemanfaatan TIK Sebagai Media Pembelajaran di SMA Sederajat Di Kecamatan Bunguran Timur Kabupaten Natuna sudah baik. Hal ini di tandai dengan tingkat kompetensi guru TIK yang tinggi. Selain itu, guru TIK juga tidak hanya memanfaatkan aplikasi pengolah slide persentasi, namun menggunakan aplikasi lain seperti pengolah audio video untuk membuat media pembelajaran yang lebih interaktif dan diminati oleh siswa. Selanjutnya, pemanfaatan TIK sebagai sumber belajar pun sudah dilakukan dengan baik. Guru dapat memaksimalkan penggunaan internet sebagai salah satu sumber belajar yang gunakan. Kemampuan guru dalam mengakses internet pun sudah berada dalam kategori yang sangat tinggi. Hal tersebut menjelaskan bahwa guru TIK di SMA sederajat di kecamatan Bunguran Timur telah memiliki kompetensi yang baik dan dapat memanfaatkan TIK secara maksimal.

\section{REFERENSI}

Anshori, S. (2017). Pemanfaatan Tik Sebagai Sumber Dan Media Pembelajaran. Jurnal Ilmu Pendidikan PKn Dan Sosial Budaya, 1(1), 10-20.

Anshori, S. (2018). Pemanfaatan Teknologi Informasi Dan Komunikasi Sebagai Media Pembelajaran. Jurnal Ilmu Pendidikan PKn Dan Sosial Budaya, 2(1), 88-100.

Chaidar, H. (2014). Pemanfaatan Teknologi Informasi dan Komunikasi dalam Pembelajaran di SMA Muhammadiyah Tarakan. Jurnal Kebijakan Dan Pengembangan Pendidikan, 2(2), 184-192.

Cholik, C. A. (2017). Pemanfaatan Teknologi Informasi dan Komunikasi Untuk meningkatkan Pendidikan Indonesia. Syntax Literate, 6(6), 5-9.

Dewi, S. Z., \& Hilman, I. (2019). Penggunaan TIK sebagai Sumber dan Media Pembelajaran Inovatif di Sekolah Dasar. Indonesian Journal of Primary Education, 2(2), 48-53. https://doi.org/10.17509/ijpe.v2i2.15100

Effendi, H., Muskhir, M., \& Rahmat, R. E. (2020). Efektivitas Metode Pembelajaran Berbasis TIK pada Mata Pelajaran Pekerjaan Dasar Elektromekanik. Edumatic: Jurnal Pendidikan Informatika, 4(1), 30-36. https://doi.org/10.29408/edumatic.v4i1.2045 
Husaini, M. (2014). Pemanfaatan Teknologi Informasi Dalam Bidang Pendidikan (Eeducation). Mikrotik, 2(1), 1-5. https://doi.org/10.31219/osf.io/ycfa2

Kemendiknas. (2007). Peraturan Menteri Pendidikan Nasional Republik Indonesia Nomor 16 Tahun 2007 Tentang Standar Kualifikasi Akademik dan Kompetensi Guru. Kemendiknas.

Lestari, S. (2015). Faktor-Faktor Yang Mempengaruhi Pemanfaatan Tik Oleh Guru. Jurnal Kwangsan, 3(2), 121-134. https://doi.org/10.31800/jurnalkwangsan.v3i2.29

Musfiqon. (2012). Pengembangan Media dan Sumber Pembelajaran. Jakarta: Prestasi Pustaka.

Nurdianti, S., \& Nurkin, A. (2016). Peran Cara Belajar Dalam Memediasi Pengaruh Internet Sebagai Sumber Belajar dan Kepercayaan Diri Terhadap Hasil Belajar Ekonomi. Economic Education Analysis Journal, 5(3), 18-23.

Rusman. (2011). Model-Model Pembelajaran Mengembangkan Profesionalisme Guru (Cetakan ke). Jakarta: Raja Grafindo Persada.

Setiyani, R. (2010). Pemanfaatan Internet Sebagai Sumber Belajar. Dinamika Pendidikan, 5(2), 117-133. https://doi.org/10.15294/dp.v5i2.4921

Sudarwan. (2012). Pengantar Kependidikan. Bandung. Alfabeta.

Tafonao, T. (2018). Peranan Media Pembelajaran Dalam Meningkatkan Minat Belajar Mahasiswa. Jurnal Komunikasi Pendidikan, 2(2), 103-114 https://doi.org/10.32585/jkp.v2i2.113 